\title{
Filtration and Electrocoagulation as a Combined Process for Electroplating Wastewater
}

\author{
Rusdianasari $^{1, *}$ Yohandri Bow ${ }^{2}$ Adi Syakdani ${ }^{3,}$ Muhammad Taufik ${ }^{3}$ \\ ${ }^{1}$ Renewable Energy Engineering Department, PoliteknikNegeri Sriwijaya, Palembang, Indonesia \\ ${ }^{2}$ Energy Engineering Department, Politeknik Negeri Sriwijaya, Palembang, Indonesia \\ ${ }^{3}$ Chemical Engineering Department, Politeknik Negeri Sriwijaya, Palembang, Indonesia \\ *Corresponding author: rusdianasari@polsri.ac.id
}

\begin{abstract}
Electroplating is a method of using electrolyte solutions to cover solid materials with metal layers. The strong metal waste from the electroplating process is contained in B3 waste (Hazardous Toxic Materials). One of the methods for electroplating is by combining filtration and electrocoagulation methods. The parameters observed in this study were total dissolved solid (TDS), $\mathrm{pH}$, conductivity, and $\mathrm{Cr}$ and $\mathrm{Ni}$ electroplating wastewater content before and after treatment. This research was conducted by adjusting the processing time and the distance between the electrode plates. The cycle time is 30,60,90, 120 and 150 minutes with an electrode spacing of 1,2 and $3 \mathrm{~cm}$. This feedback is to the activated carbon filter and the silica sand by the electrocoagulation process using aluminum electrodes. The feedback is filtered with a cartridge filter and a reverse osmosis (RO) filter. The results show that the optimum TDS, pH, conductivity and levels of $\mathrm{Cr}$ and $\mathrm{Ni}$ occur at a processing time of 150 minutes at an electrode distance of $1 \mathrm{~cm}$. The $\mathrm{pH}$ value rose from 5.63 to 7.89 , and the TDS decreased from $234 \mathrm{ppm}$ to $73.6 \mathrm{ppm}$. Conductivity also decreased from $1466 \mu \mathrm{s} / \mathrm{cm}$ to $148.5 \mu \mathrm{s} /$ $\mathrm{cm}$. $\mathrm{Cr}$ and Ni have decreased from $8.43 \mathrm{ppm}$ to $0.29 \mathrm{ppm}$ and from $9.288 \mathrm{ppm}$ to $0.893 \mathrm{ppm}$. The outcomes of this waste treatment met the requirements for clean water (Regulation of the Minister of Health of the Republic of Indonesia, No 32 of 2017) and industrial wastewater (Regulation of the Minister of the Environment of the Republic of Indonesia, No 5 of 2014).
\end{abstract}

Keywords: electrode, electroplating, electrocoagulation, filtration

\section{INTRODUCTION}

Metals such as iron, brass and aluminium are commonly used as industrial and domestic products. In order to improve surface quality, particularly in terms of beauty and corrosion resistance, this industrial material must be coated with stainless metals such as silver, nickel and chromium. Electroplating or gilding is a method of coating a solid material with a metal layer by letting the electrical current flows through an electrolyte solution. The strong metal waste from the electroplating process is contained in B3 waste (Hazardous Toxic Materials) [1-2].

Some of the metal elements in electroplating wastewater include iron, chromium, zinc, nickel, manganese and copper. The amount of waste produced in the electroplating process is not too high, but the level of toxicity, particularly chromium, nickel and zinc, is hazardous. The characteristics and toxicity of wastewater electroplating differ according to operational conditions, the method of coating, and procedure of washing [3-6].

The direct disposal of waste from the electroplating process to the environment without prior treatment can cause environmental pollution. These contaminants can contaminate microorganisms and their environment in the form of solutions, colloids and other types of particle. Given the significance and magnitude of the environmental effects, treatment is required before waste effluent is discharged into the environment [7-9].

Some methods used to treat electroplating waste include precipitation, microorganisms, ultrafiltration, reverse osmosis, and others. Precipitation is the most economical process, but precipitation is also capable of creating added chemical waste. Other methods also have disadvantages, such as the high cost necessary and difficult to achieve on an industrial scale [10-14].

The electrocoagulation approach is another alternative that can be used for electroplating waste treatment. Electrocoagulation is a process that is effective and simple to operate to minimize heavy metal 
content by electrolysis reactions and does not involve the addition of chemical coagulants[15-18].

In 1995, Matteson introduced an electronic coagulator in which the electrical current applied to the anode would dissolve aluminium into a solution that would then react with hydroxy ions (from the cathode) to form hydroxy aluminium. Hydroxy flocculates and coagulates suspended particles resulting in a method of separation of solids from wastewater $[19,20]$.

This is illustrated by a number of previous studies. One example is the research conducted by Ratnawati [20], who treated electrocoagulation waste using $\mathrm{Fe}$ electrodes. Electroplating waste treatment using electrocoagulation is known to be capable of reducing $\mathrm{Cu}, \mathrm{Ni}$ and $\mathrm{Cr}$ concentrations at the lowest concentrations.

The electroplating wastewater treatment with electrocoagulation methods in this study is conducted using different electrodes from previous studies. In earlier studies, the electrodes used are aluminium electrodes. The parameters observed in this study were TDS, $\mathrm{pH}$, conductivity, and $\mathrm{Cr}$ and $\mathrm{Ni}$ electroplating wastewater content before and after treatment. This research was performed by adjusting the processing time and distance of the electrode.

\section{RESEARCH METHODE}

This research was conducted to determine the characteristics of electroplating waste prior to and after treatment with a combination of filtration and electrocoagulation processes. The electroplating waste to be used is extracted from the $\mathrm{Cr}$ and $\mathrm{Ni}$ coating in the Kertapati region in Palembang, South Sumatra. The parameters observed were TDS, $\mathrm{pH}$, conductivity, and $\mathrm{Cr}$ and $\mathrm{Ni}$ contents.

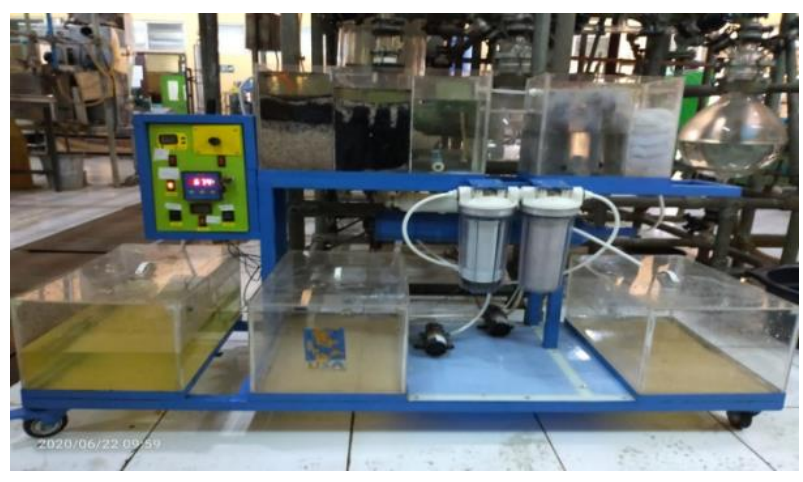

Figure 1 Combination of Filtration and Electrocoagulation Process for electroplating wastewater

The materials used in this study were aluminium plate electroplating waste as an electrode with dimensions of $22 \times 12.5 \mathrm{~cm}, \mathrm{Cr}$ and $\mathrm{Ni}$ standard solutions and $\mathrm{H}_{2} \mathrm{SO}_{4}$.

The instruments used in this study included a range of electrocoagulators, Waterproof cyberscan PCD 650, GBC AAS 932 Plus and ICP-OES.
The data collection stage was focused on variations in processing time and electrode distance. Sample treatment varied with processing times of 30,60, 90, 120 and 150 minutes and with electrode distances of 1 , 2 and $3 \mathrm{~cm}$. The electroplating waste management method with a filtration and electrocoagulation device is shown in Figure 1.

\section{RESULTS AND DISCUSSION}

\subsection{Results of Characterization of Electroplating Waste before the Filtration and Electrocoagulation Process}

Electroplating wastewater is first characterized before filtration and electrocoagulation treatment to establish the initial conditions of electrification waste before treatment. The results of the characterization of electroplating waste are shown in Table 1.

Table 1. Results of initial characterization of electroplating waste

\begin{tabular}{|c|c|c|c|}
\hline No. & Parameter & Results & Standard* \\
\hline 1 & TDS $(\mathrm{ppm})$ & 234 & 1000 \\
\hline 2 & $\mathrm{pH}$ & 5.63 & $6-9$ \\
\hline 3 & Conductivity $(\mu \mathrm{s} / \mathrm{cm})$ & 1466 & $20-1500$ \\
\hline 4 & $\mathrm{Cr}(\mathrm{ppm})$ & 8.43 & 0.5 \\
\hline 5 & $\mathrm{Ni}(\mathrm{ppm})$ & 9.288 & 0.1 \\
\hline
\end{tabular}

* Regulation of the Minister of the Environment of the Republic of Indonesia, No 5 of 2014

*Regulation of the Minister of Health of the Republic of Indonesia, No 32 of 2017.

\subsection{Effect of Electrode Distance and Processing Time on TDS}

TDS (Total Dissolved Solids) is the quantity of substance dissolved in water. This substance can be in the form of carbonate, bicarbonate, chloride, sulfate, nitrate, calcium, magnesium, sodium, organic ions, colloidal compounds and others. TDS can be used to measure the consistency of drinking water since it represents the number of ions in the water. The value of the water quality criteria for the TDS test parameters approved under the national standard is $1000 \mathrm{ppm}$ (Health Minister of the Republic of Indonesia, 2017).

Figure 2 indicates that the TDS value in the waste sample decreased by $234 \mathrm{ppm}$ from the initial TDS after passing through the electrocoagulator. After processing, the TDS value decreased to $73.6 \mathrm{ppm}$. This condition occurs at a processing time of 150 minutes and an electrode distance of $1 \mathrm{~cm}$. The effects of this decrease show that the longer the processing time and the closer the electrode size, the lower the TDS value. The waste is treated with aluminium electrodes with a distance range of 1,2 and $3 \mathrm{~cm}$. The variation of the electrode distance is matched to the width of the electrocoagulation bath. The electrode distance of $1 \mathrm{~cm}$ 
produces more coagulants than the electrode distances of 2 and $3 \mathrm{~cm}$. Process time and electrode distance can affect the rate of formation of the coagulant, regulate the speed and size of the bubbles and the growth of the floc, which may bind the pollutants to the waste so that more floc is created. The bubbles produced during the electrocoagulation phase bring up the contaminants in the waste so that the current contaminants can be easily collected together. The $\mathrm{Al}^{3+}$ ion produced at the anode reacts with the $\mathrm{OH}$-ion generated at the cathode to form $\mathrm{Al}(\mathrm{OH})_{3}$ which binds existing pollutants so that they can be precipitated more easily.

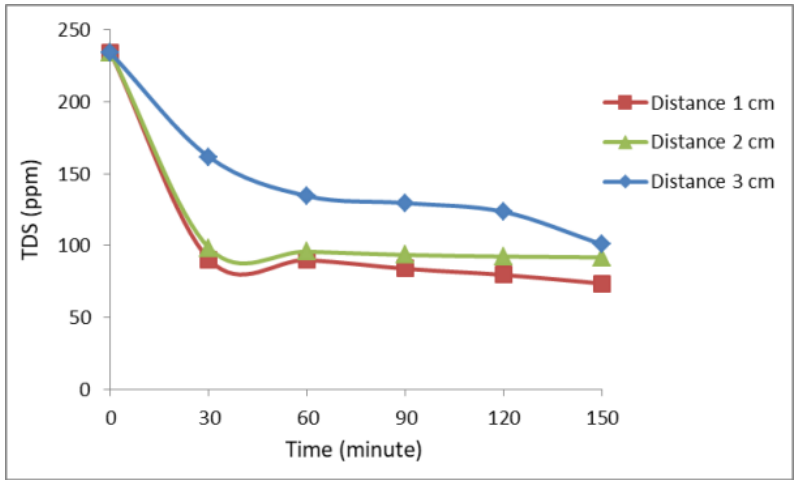

Figure 2 Effect of electrode distance and processing time on TDS

\subsection{Effect of Electrode Distance and Processing Time on $\mathrm{pH}$}

The $\mathrm{pH}$ is the concentration of hydrogen ions $\left(\mathrm{H}^{+}\right)$ in water. The $\mathrm{pH}$ value is significant as a water quality parameter because it can monitor the form and rate of multiple reactions in the water. The increase in $\mathrm{pH}$ value in the electrocoagulation process is due to the addition of alkaline $\mathrm{Al}^{3+}$ ions to the water. As accumulation occurs, the hydrolysis of the water induces a reaction to the hydroxyl ion. This reaction produces 3 ions of $\mathrm{Al}$ $(\mathrm{OH})$ and hydrogen.

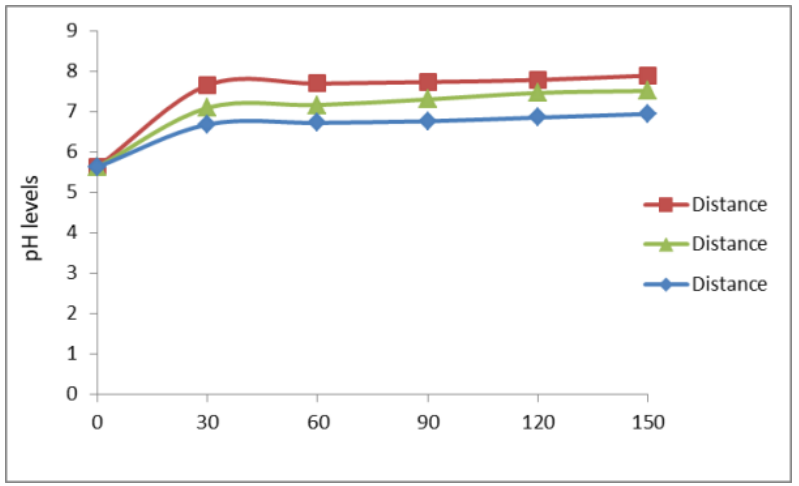

Figure 3 Effect of electrode distance and processing time on $\mathrm{pH}$

Electroplating waste was electrocoagulated with aluminium electrodes with distance variations of 1,2 , and $3 \mathrm{~cm}$. Based on Figure 3, the $\mathrm{pH}$ value of the electroplating waste sample from the initial $\mathrm{pH}$ of 5.63 (acid) is increased. The closer the electrode gap results in the increment of $\mathrm{pH}$ value. Following sampling, the $\mathrm{pH}$ value has increased to 7.89 (neutral) with a processing time of 150 minutes and an electrode distance of $1 \mathrm{~cm}$. Water electrolysis produces hydrogen gas ions and hydroxide ions in the electrocoagulation process. The radius of $1 \mathrm{~cm}$ from the electrode accelerates ion exchange by 2 to $3 \mathrm{~cm}$ from the electrode.

Moreover, the longer the treatment time, the quicker hydrogen gas and hydroxide ions can form. The hydroxide ion reaction produces a coefficient more significant than the hydrogen coefficient. This result shows that hydroxide ion formation happens when the size of the electrode is closer, and the treatment time is longer. This condition raises acidity to close or neutral $\mathrm{pH}$.

\subsection{Effect of Electrode Distance and Processing Time on Conductivity}

Conductivity is a measure of the ability of a substance to conduct electrical current. Water conductivity is directly related to the concentration of dissolved solids ionized in water. Conductivity is also known as specific conductivity. Conduct $(\mathrm{G})$ is the inverse of resistance $(\mathrm{R})$. Each material has specific properties, which are defined as resistivity $(\rho)$ in ohmmeters $(\mathrm{P})$.

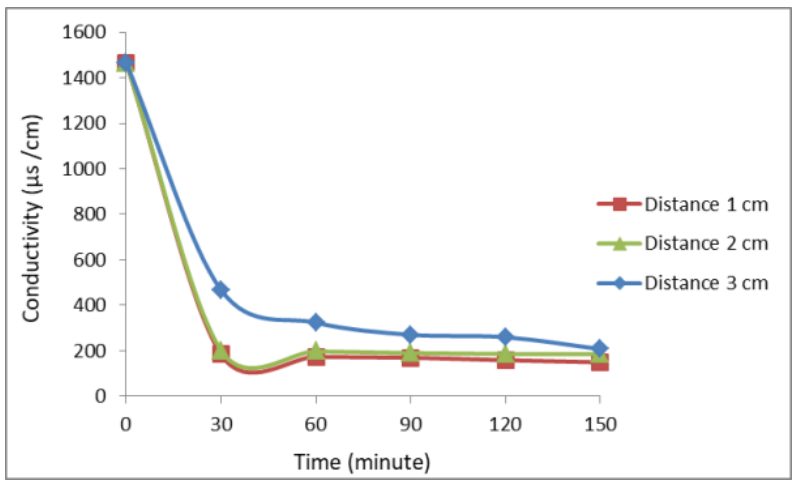

Figure 4 Effect of electrode distance and processing time on conductivity

Electroplating waste treatment is carried out by an electrocoagulation device that uses electricity in the process. The electrodes used are aluminium with distance variations of 1,2 , and $3 \mathrm{~cm}$, which affect the conductivity value of the treated waste. Figure 4 shows that the conductivity value in the waste sample decreased from an initial conductivity of $1466 \mu \mathrm{s} / \mathrm{cm}$ to $148.5 \mu \mathrm{s} / \mathrm{cm}$ after passing through the electrocoagulator. This condition occurs at a processing time of 150 minutes and at an electrode distance of $1 \mathrm{~cm}$. The effects of this decrease show that the longer the processing time and the closer the electrode gap, the 
lower the conductivity value. The electrode distance of $1 \mathrm{~cm}$ accelerates the ion exchange compared to the electrode distances of 2 and $3 \mathrm{~cm}$, making the coagulant faster. Process time and electrode distance can affect the rate of formation of the coagulant, regulate the speed and size of the bubbles and the growth of the floc, which may bind the pollutants to the waste so that more floc is created. The number of ions influences the conductivity value in the solution. The greater the number of dissolved solids, the greater the number of ions in the solution, since the amount of dissolved solids includes ions which are arranged into dissolved solid compounds. This result indicates that the importance of TDS and conductivity would have a close relationship.

\subsection{Effect of Electrode Distance and Processing Time on $\mathrm{Cr}$}

Chromium (Cr) is a metal with a high degree of toxicity. $\mathrm{Cr}$ metal in the electroplating industry is used in the hard-coat process to be anti-dull. The toxic effect of $\mathrm{Cr}$ from electroplating waste can be bioaccumulative and can not be decomposed. The $\mathrm{Cr}$ content data obtained by Atomic Adsorption Spectrophotometer measurement were analyzed to determine the relationship between $\mathrm{Cr}$ metal absorption and processing time and electrode distance. The electrodes used are aluminium with a distance variation of 1,2 and $3 \mathrm{~cm}$.

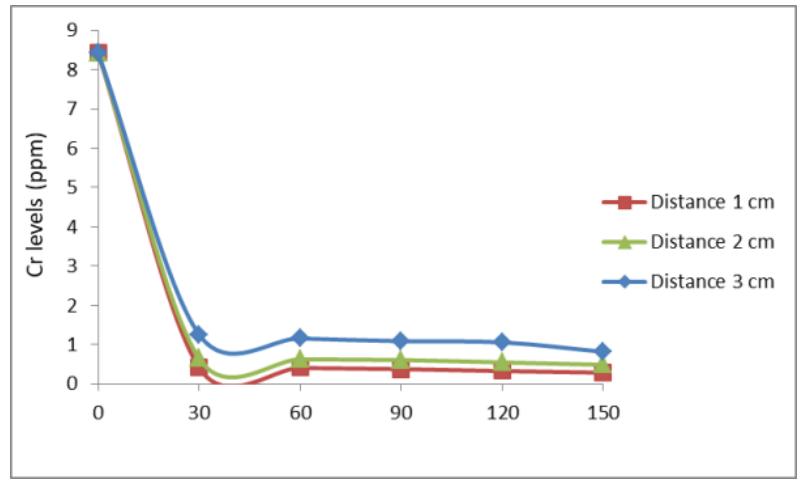

Figure 5 Effect of electrode distance and processing time on $\mathrm{Cr}$

Figure 5 demonstrates the effects of electroplating waste treatment by electrocoagulation technology. The initial $\mathrm{Cr}$ content for electroplating waste was $8.43 \mathrm{ppm}$. The $\mathrm{Cr}$ content decreased along with the longer the processing time and the closer the electrode distance so that the optimum $\mathrm{Cr}$ content was $0.29 \mathrm{ppm}$ at 150 minutes of processing time and $1 \mathrm{~cm}$ of electrode distance. This condition occurs due to more coagulants generated by the long processing time and the close electrode gap. The higher the coagulant mass, the simpler the $\mathrm{Cr}(\mathrm{OH})_{3}$ precipitates to form and the lower the $\mathrm{Cr}$ metal content. Electrode distance of $1 \mathrm{~cm}$ accelerates ion-exchange compared to electrode distances of 2 and $3 \mathrm{~cm}$. Cr metal in waste interacts with $\mathrm{OH}^{-}$ion, which allows $\mathrm{Cr}$ to precipitate in waste to form $\mathrm{Cr}(\mathrm{OH})_{3}$. The $\mathrm{Cr}(\mathrm{OH})_{3}$ deposit can act as a floc centre that is electropositive and absorbs excess $\mathrm{OH}^{-}$in the solution so that it forms a floc and can draw other metal cations to the waste..

\subsection{Effect of Electrode Distance and Processing Time on Ni Metal Content}

Nickel is used in the electroplating industry for decorative coatings of $\mathrm{Cr}$ metal coating steel parts. Ni metal is also metal with a hazardous toxicity level. Ni material data collected through Atomic Adsorption Spectrophotometer measurements were analyzed to determine the relationship between $\mathrm{Ni}$ metal absorption and processing time and electrode distance.

Electroplating wastewater is treated using aluminium electrodes, which vary in distance gap from 1,2 and $3 \mathrm{~cm}$ apart during electrocoagulation process. Figure 6 shows that Ni levels decreased from an initial $\mathrm{Ni}$ level of $9.288 \mathrm{ppm}$ after being treated with electrocoagulation technology. $\mathrm{Ni}$ levels decreased together with the more extended the processing time and the closer the electrode distance so that the optimum $\mathrm{Ni}$ content was $0.893 \mathrm{ppm}$ at 150 minutes of processing time and $1 \mathrm{~cm}$ of electrode distance. This result is due to more coagulants will be generated by the long processing time and the closer electrode gap. The electrode distance of $1 \mathrm{~cm}$ accelerates the ion exchange compared to the electrode distances of 2 and $3 \mathrm{~cm}$ so that more coagulants are produced. The more coagulant mass ratio allows the formation of $\mathrm{Al}(\mathrm{OH})_{3}$ deposits. The more coagulant the mass and the higher the $\mathrm{pH}$ value, the more $\mathrm{OH}$ ions react with $\mathrm{Ni}$ Metal to form $\mathrm{Ni}(\mathrm{OH})_{2}$ precipitates in the waste.

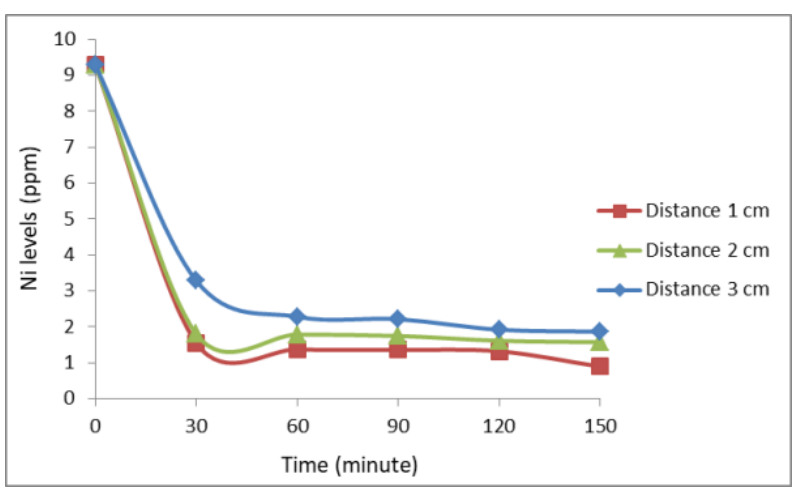

Figure 6 Effect of electrode distance and processing time on Ni metal content

The objective of electroplating waste treatment using electrocoagulation in this study is to compare the reduction of pollutants in electroplating waste before and after treatment. The results of this study show that it is suitable for public consumption based on clean water standards (Regulation of the Ministry of Health of the 
Republic of Indonesia No. 32 of 2017) and industrial wastewater standards (Regulation of the Ministry of Health of the Republic of Indonesia No. 32 of 2017).

Aluminium electrodes are used in this processing since it is inexpensive and easy to find. The results show that the Al-Al electrode is the optimal electrode. This mixture is used for further optimisation. The most floc formed in the combination of $\mathrm{Al}-\mathrm{Al}$ electrodes is the aluminium electrodes quickly form $\mathrm{Al}(\mathrm{OH})_{3}$ hydroxide and complex hydroxyl polymers. The more flocks that are created, the more contaminants are consumed to make the reduction of pollutants in electroplating liquid waste more optimal. The reaction in the electrode cell to the anode and cathode used in aluminium is as follows:

Reaction on the anode:

$\mathrm{Al} \longrightarrow \mathrm{Al}^{3+}+3 \mathrm{e}$

The anodic process leads to the aluminium metal being dissolved into $\mathrm{Al}^{3+}$ ion molecules. The formed ions are hydrolysed and produce solid $\mathrm{Al}(\mathrm{OH})_{3} \cdot \mathrm{xH}_{2} \mathrm{O}$ that can not be dissolved in water. The Response:

$$
\mathrm{Al}+3 \mathrm{H}_{2} \mathrm{O} \longrightarrow \mathrm{Al}(\mathrm{OH})_{3} \cdot \mathrm{xH}_{2} \mathrm{O} \cdot \mathrm{Al}(\mathrm{OH})_{3} \cdot \mathrm{xH}_{2} \mathrm{O}
$$

The reaction is produced in a solution that can serve as a coagulant for the coagulation-flocculation phase that occurs in the next electrocoagulation cell process.

The reaction at the cathode:

$$
2 \mathrm{H}_{2} \mathrm{O}+2 \mathrm{e} \longrightarrow \mathrm{H}_{2}+2 \mathrm{OH}^{-}
$$

Based on the results of the study, it is established that the optimum TDS, $\mathrm{pH}$, conductivity and levels of $\mathrm{Cr}$ and $\mathrm{Ni}$ are observed at 150 minutes of processing time and $1 \mathrm{~cm}$ of electrode distance. This result proves that the longer the processing time and the closer the distance between the electrodes would result in more coagulants. The increase increment of coagulants has increased the $\mathrm{pH}$ value, while the TDS value and conductivity, as well as the $\mathrm{Cr}$ and $\mathrm{Ni}$ levels, have decreased.

\section{CONCLUSION}

The results of electroplating waste characterization after treatment by filtration and electrocoagulation showed changes. The $\mathrm{pH}$ value rose from 5.63 to 7.89 , and the TDS decreased from $234 \mathrm{ppm}$ to $73.6 \mathrm{ppm}$. Conductivity also decreased from $1466 \mu \mathrm{s} / \mathrm{cm}$ to 148.5 $\mu \mathrm{s} / \mathrm{cm}$. Cr and Ni have decreased from $8.43 \mathrm{ppm}$ to 0.29 ppm and from $9.288 \mathrm{ppm}$ to $0.893 \mathrm{ppm}$.

Process time and electrode distance in the electrocoagulation method affect the consistency of the electroplating waste properties. The longer the processing time and the closer the distance between the electrodes would result in more coagulants. The coagulants increment has increased the $\mathrm{pH}$ value, while the TDS value and conductivity, as well as the $\mathrm{Cr}$ and Ni levels, have decreased.

Based on the results of the analysis, the optimum levels of TDS, $\mathrm{pH}$, conductivity, and $\mathrm{Cr}$ and $\mathrm{Ni}$ were detected at 150 minutes of processing time and $1 \mathrm{~cm}$ of electrode distance.

\section{AUTHORS' CONTRIBUTIONS}

All of the authors are involved in the process of designing the equipment and analysis electroplating wastewater. The first and corresponding author contribution is responsible for data processing and manuscript writing. The second author is responsible for equipment design and data processing. The third author is responsible for analysis sample electroplating wastewater. The fourth author is responsible for funding arrangement.

\section{ACKNOWLEDGMENTS}

This work was sponsored by the Politeknik Negeri Sriwijaya through the Assignment Grant of 2020.

\section{REFERENCES}

[1] Rusdianasari, A Taqwa, Jaksen, A Syakdani, Treatment Optimization of Electrocoagulation (EC) in Purifying Palm Ool Mill Effluents (POMEs), J. Eng. Technol. Sci., Vol. 49, No. 5, 2017, pp. 604617

[2] A Meidinariasty, Rusdianasari, Y Bow, I Rusnadi, A.L. Fuadi, Treatment of Leachate from Garbage using Electrocoagulation Type MP-P (MonopolarParalel) Methode, Journal of Physic: Conf. Series 1167 (012054), 2019

[3] Rusdianasari, Y Bow, $\mathrm{T}$ Dewi, Peat Water Treatment br Electrocoagulation using Aluminium Electrodes, IOP Conf. Series: Earth and Environmental Science 258 (012013), 2019

[4] K Dermentzis, A Christoforidis, E Valvasamidou, Removal of Nickel, Copper, Zinc and Chromium from Synthetic and Industrial Wastewater by Electrcoagulation, Int. Journal of Environmental Sciences, Vol. 1 No. 5, 2011, pp. 697-710

[5] K Dermentzis, A Christoforidis, E Valvasamidou, A Lazaridou, N Kokkinos, Removal of Hexavalent Chromium from Electroplating Wastewater by Electrcoagulation with Iron Eelctrodes, Global NEST Journal, Vol. 13 No. 4, 2011, pp. 412-418

[6] Bazrafshan, E., and Hussain Moen, Applicatioon of Electrocoagulation Process for Dairy Wastewater Treatment. Journal of Chemistry. Article ID 640139: 8 pages, 2013

[7] R. Bow, S. Arita, E. Ibrahim, N. Ngudiantoro, Reduction of Metal Contents in Coal Stockpile Wastewater using Electrocoagulation, Appl. Mech. and Mat. 391, 2013, pp 29-33

[8] Rusdianasari, A. Meidinariasty, I. Purnamasari, Level Decreasing Kinetics Model of Heavy Metal 
Contents in the Coal Stockpile Wastewater with Electrocoagulation, Int. J. on Adv. Sci. Eng. and Information Tech. Vol. 5, No. 6, 2015, pp 387-391

[9] Rusdianasari, Y. Bow, A. Taqwa, Treatment of Coal Stockpile Wastewater by Electrcocoagulation using Aluminium Electrodes, Adv. Materials Res. 896,2014, pp 145-148

[10] Rusdianasari, A. Taqwa, Jaksen, and A. Syakdani, Treatment of Landfill Leachate by Electrocoagulation using Aluminum Electrode, Matec Web of Conference 101 (02010), 2017

[11] E Butler, Y T Hung, R Y L Yeh, M S A Ahmad, Electrocoagulation in Wastewater Treatment, Water, Vol. 3, 2011, pp. 495-525, doi:10.3390/w320495

[12] Njiki, C. P. N., S.R. Tchamango, P.C. Ngom, A. Darchen and E. Ngameni. 2009. Mercury(II) Removal from Water by Electrocoagulation using Aluminium and Iron Electrodes. International Journal of Enviromental Research. Vol 4(2): 201 208.

[13] Rusdianasari, Jaksen, A Taqwa, Y Wijarnako, Effectiveness of Electrocoagulation Method in Processing Integrated Wastewater by Aluminium and Stainless Steel Electrodes, Journal of Physic: Conf. Series 1167 (012040), 2019

[14] Holt, P. K. 2012. A Quantitative Comparison Between Chemical Dosing and Electrocoagulations. Colloids and Surface A: Physicochem. Eng. Aspects, 211: 233-248.
[15] R.M. Bhise, A.A. Patil, A.R. Raskar, P.J. Patil and D.P. Deshpande. "Removal of Colour of Spent Wash by Activated Charcoal Adsorption and Electrocoagulation." Res.J.Recent Sci. vol. 1, no. 6, pp. 66-69. 2015.

[16] Y. Avsar, U. Kurt, and T. Gonullu, Comparison of classical chemical and electrochemical processes for treating rose processing wastewater, J. of Hazardous Materials, vol. 148, pp. 340-345. 2007.

[17] M. Kobya, O.T. Can and M. Bayramoglu, Treatment of textile wastewaters by electrocoagulation using iron and aluminum electrodes, Journal of Hazardous Materials. vol. B10, pp. 163-178. 2003.

[18] Rusdianasari, Jaksen, A. Taqwa and Y. Wijarnako, Smart Sensor for Monitoring Integrated wastewater, IOP Conference Series: Earth and Environmental Science. vol. 347, no. 1, pp. 012061. 2019.

[19] Rusdianasari, I. Hajar and I. Aryanti, Songket Industry Wastewater Processing using Electrocoagulation Method, Jurnal Rancang Bangun dan Teknologi. vol. 19, no. 10, pp. 47-53. 2019.

[20] C. Tian, R. Tian, Y. Zhou, Q. Chen and H. Cheng, Decolorization of indigo dye and indigo dyecontaining textile effluent by Ganoderma weberianum, African J. of Microbiology Research. vol. 7, no. 11, pp. 941-947. 2013. 